\title{
Pengaruh Penambahan Sekam Padi dengan Tambahan Serat Pinang Terhadap Sifat Fisik dan Mekanik Papan Beton Ringan
}

\author{
Ressi Anggraini*, Alimin Mahyudin** \\ Laboratorium Fisika Material \\ Fakultas Matematika dan Ilmu Pengetahuan Alam Universitas Andalas \\ Kampus Unand Limau Manih, Padang,25163, Indonesia \\ *ressyanggraini7@gmail.com,**aliminmahyudin23@gmail.com
}

\begin{abstract}
ABSTRAK
Telah dilakukan penelitian tentang pengaruh penambahan sekam padi dengan tambahan serat pinang terhadap sifat fisik dan mekanik papan beton ringan. Penambahan sekam padi yang digunakan adalah $0 \%, 10 \%, 20 \%, 30 \%$ dan $40 \%$. Pengujian sifat fisik dan mekanik yang diuji meliputi densitas, porositas, daya serap air dan kuat tekan dengan ukuran sampel $5 \mathrm{~cm}$ x $5 \mathrm{~cm}$ x $1 \mathrm{~cm}$, sedangkan kuat lentur dengan ukuran sampel $20 \mathrm{~cm}$ x $5 \mathrm{~cm}$ x $1 \mathrm{~cm}$. Nilai densitas minimum yaitu $1,48 \mathrm{~g} / \mathrm{cm}^{3}$ terdapat pada penambahan sekam padi $40 \%$. Daya serap air mengalami kenaikan dengan bertambahnya sekam padi pada persentase $40 \%$ yaitu $15,84 \%$. Nilai porositas semakin naik seiring bertambahnya persentase sekam padi, dimana nilai maksimum terdapat pada persentase $40 \%$ yaitu $23,78 \%$. Kuat tekan maksimum yaitu $56,33 \mathrm{~kg} / \mathrm{cm}^{2}$ pada persentase sekam padi 10\% dan hampir mendekati SNI 03-3449-2002, sedangkan untuk nilai kuat lentur maksimum yaitu $38,83 \mathrm{~kg} / \mathrm{cm}^{2}$ pada persentase $10 \%$. Hasil pengujian menyatakan papan beton ringan dengan variasi sekam padi telah memenuhi SNI 03-3449-2002 dengan nilai densitas $<1,90 \mathrm{~g} / \mathrm{cm}^{3}$. Kata kunci: papan beton, kuat tekan, kuat lentur, densitas, daya serap air dan porositas
\end{abstract}

\section{ABSTRACT}

Research on the effect of rice husk addition with additional fiber on the physical and mechanical properties of lightweight concrete boards has been conducted. The addition of rice husk used was $0 \%$, $10 \%, 20 \%, 30 \%$ and 40\%. The physical and mechanical properties test included density, porosity, water absorption and compressive strength with a sample size of $5 \mathrm{~cm} \times 5 \mathrm{~cm} \times 1 \mathrm{~cm}$, while the flexural strength with a sample size of $20 \mathrm{~cm} \times 5 \mathrm{~cm} \times 1 \mathrm{~cm}$. The minimum density value of $1.48 \mathrm{~g} / \mathrm{cm}^{3}$ is found in the addition of $40 \%$ rice husk. Water absorption has increased with the increase in rice husk at a percentage of $40 \%$, which is $15.84 \%$. The value of porosity increases with the increase in the percentage of rice husk, where the maximum value is at the percentage of $40 \%$, namely $23.78 \%$. The maximum compressive strength is $56.33 \mathrm{~kg} / \mathrm{cm}^{2}$ in the percentage of 10\% rice husk and is almost close to SNI 03-3449-2002, while for the maximum flexural strength value is $38.83 \mathrm{~kg} / \mathrm{cm}^{2}$ at a percentage of $10 \%$. The test results stated that lightweight concrete board with variations of rice husk had met SNI 03-3449-2002 with a density value $<1.90 \mathrm{~g} / \mathrm{cm}^{3}$.

Keywords: concrete board, compressive strength, flexural strength, density, water absorption and porosity

\section{PENDAHULUAN}

Meningkatnya pembangunan di Indonesia, maka kebutuhan akan bahan bangunan khususnya papan beton juga semakin meningkat. Papan beton yang dibutuhkan adalah kuat, ringan, dan hemat bahan baku. Papan beton banyak digunakan sebagai partisi bagunan dan langit-langit rumah seperti pada GRC board (Glass-Fiber Reinforced Cement) yang berkembang dipasaran. GRC adalah material komposit yang terdiri dari semen Portland, pasir, dan diperkuat dengan serat kaca. Pemanfaatan serat kaca pada papan GRC juga terbatas karena materinya terbuat dari bahan sintetik yang tidak dapat diperbarui atau didaur ulang sehingga dapat mencemari lingkungan. Untuk mengatasi permasalahan ini perlu dilakukan penelitian lebih lanjut mengenai pembuatan papan beton ringan yang berserat alam dan tidak mencemari lingkungan.

Komposit merupakan suatu material yang terbentuk dari kombinasi dua atau lebih material pembentuknya melalui campuran yang tidak homogen, dimana sifat mekanik dari masing-masing material pembentuknya berbeda. Bahan komposit pada umumnya terdiri dari dua unsur, yaitu filler sebagai bahan pengisi dan matriks sebagai bahan pengikat serat. Untuk pembuatan papan beton ringan dapat digunakan agregat ringan dari alam.

Salah satu agregat ringan yang bisa digunakan yaitu sekam padi. Sekam padi mengandung selulosa dan silika yang berfungsi sebagai filler pada pengisian papan beton 34 
ringan. Sekam padi juga memiliki massa jenis $0,11 \mathrm{gr} / \mathrm{m}^{3}$. Selain agregat, papan beton ringan ditambahkan serat alam yang bisa dijadikan sebagai bahan penguat komposit. Keuntungan mendasar yang dimiliki oleh serat alam adalah dapat diperbarui dan tidak mencemari lingkungan (Renreng, 2015). Penambahan serat pada papan beton dimaksud untuk memperbaiki sifat kuat lentur yang rendah. Serat alam yang digunakan adalah serat pinang karena memiliki densitas rendah, kekakuan tinggi, dan mudah didapat. Selain itu serat pinang memiliki selulosa dan hemiselulosa yang akan memberikan tambahan kekuatan ikat antar partikel akibat sifat adhesi, serta menghambat difusi air akibat sifat hidrofobiknya.

Sylvia (2017) menemukan bahwa nilai kuat lentur paling tinggi terdapat pada persentase serat sabut pinang $1,5 \%$ yaitu sebesar $1,944 \mathrm{~kg} / \mathrm{cm}^{2}$. Untuk nilai kuat tekan paling tinggi pada persentase serat sabut pinang $1 \%$ yaitu sebesar $76,36 \mathrm{~kg} / \mathrm{cm}^{2}$. Nilai densitas terendah terdapat pada persentase serat sabut pinang $1 \%$ yaitu sebesar $1,41 \mathrm{~g} / \mathrm{cm}^{3}$. Nilai daya serap air tertinggi juga terdapat pada persentase serat sabut pinang $1 \%$ yaitu sebesar $28,42 \%$ dan nilai daya serap air terendah sebesar $23,51 \%$ terdapat pada persentase serat sabut pinang $0 \%$ hal ini disebabkan pada persentase papan gipsum-beton yang dicetak tidak memiliki kandungan serat sehingga tidak terdapat pori-pori.

Widiatmoko dkk., (2016) menemukan bahwa berat jenis bata ringan diperoleh berkisar $1638 \mathrm{~kg} / \mathrm{cm}^{3}-1707 \mathrm{~kg} / \mathrm{cm}^{3}$ dari persentase $0 \%, 0,25 \%, 0,5 \%, 0,75 \%, 1 \%$. Berat jenis menurun seiring dengan penambahan sekam padi. Kuat tekan paling tinggi terdapat pada penambahan sekam padi $0,5 \%$ yaitu 5,30 MPa, dengan nilai kuat tekan terendah pada persentase $1 \%$. Hasil pengujian daya serap air meningkat seiring dengan meningkatnya jumlah sekam padi pada bata ringan. Penyerapan maksimum terdapat pada bata ringan dengan kadar penambahan sekam padi $1 \%$ yaitu $1,68 \%$. Penelitian ini melakukan uji densitas, kuat tekan dan daya serap air.

\section{METODE}

Pembuatan papan beton ringan serta pengujian daya serap air, densitas dan porositas dilaksanakan di Laboratorium Fisika Material Jurusan Fisika Universitas Andalas. Pengujian kuat tekan dan kuat lentur dilakukan di Laboratorium Mekanik Politeknik Negeri Padang. Bahan yang digunakan dalam penelitian ini adalah sekam padi yang berguna sebagai pengganti agregat halus berupa pasir dengan ukuran partikel lulus ayakan 50 mesh dengan variasi $0 \%, 10 \%, 20 \%, 30 \%$ dan $40 \%$ serta serat pinang yang berguna sebagai ikatan matrik yang panjangnya $1 \mathrm{~cm}$ sebesar $1,5 \%$. Bahan matriks yang digunakan adalah semen, pasir dan air. Papan beton ringan yang dibuat berukuran $5 \times 5 \times 1 \mathrm{~cm}^{3}$ untuk pengujian densitas, daya serap air, porositas, dan kuat tekan. Pengujian kuat lentur dilakukan pada sampel dengan ukuran $20 \mathrm{x}$ $5 \times 1 \mathrm{~cm}^{3}$.

Sekam padi yang didapat dari hasil limah kulit padi terlebih dahulu dicuci untuk menghindari adanya pengotor berupa tanah. Kemudian sekam padi di jemur dibawah terik matahari selama 1 hari untuk menghilangkan air yang masih tersisa. Setelah itu sekam padi digiling dan diayak dengan ayakan 50 mesh. Pemisahan serat pinang dilakukan secara manual meliputi perendaman dan pemisahan serat. Serat pinang yang digunakan dipotong sepanjang 1 $\mathrm{cm}$. Serat direndam dengan larutan $5 \% \mathrm{NaOH}$ selama $2 \mathrm{jam}$. Kemudian serat pinang dibilas dengan aquades untuk menghilangkan kandungan $\mathrm{NaOH}$ yang tersisa. Selanjutnya serat pinang dikeringkan dibawah terik matahari untuk menghilangakan kadar air yang tersisa.

Tahap - tahap pembuatan papan beton ringan adalah sebagai berikut, tahap pertama adalah pembuatan pasta beton dengan mencampurkan semen, pasir dan sekam padi. Semen dan agregat diaduk hingga merata kemudian air dituangkan sedikit demi sedikit dengan perbandingan air dan semen 0,4:1. Foam Agent diaduk dengan air hingga membentuk busa, hasil adukan digabungkan ke dalam campuran mortar. Pasta beton kemudian dituangkan kedalam cetakan dengan ukuran $5 \mathrm{~cm} \times 5 \mathrm{~cm} \times 1 \mathrm{~cm}$ untuk uji densitas, daya serap air, porositas dan kuat tekan untuk uji kuat lentur digunakan ukuran cetakan $20 \mathrm{~cm}$ x $5 \mathrm{~cm} \times 1 \mathrm{~cm}$. Permukaan sampel diratakan dengan sendok semen dan didiamkan dalam cetakan selama 24 jam. Setelah itu sampel uji yang terbentuk dikondisikan pada suhu ruang selama 28 hari sebelum digunakan untuk pengujian sesuai standar. 


\subsection{Pengujian Daya Serap Air}

Mula-mula sampel uji direndam pada suhu ruang selama 24 jam. Lalu sampel uji diangkat dan dikeringkan dengan kain hingga airnya tidak menetes lagi. Kemudian sampel uji ditimbang menggunakan neraca digital dan dicatat hasilnya sebagai $m_{b}$. setelah itu dilakukan perhitungan menggunakan Persamaan 1.

$$
\text { dayaserapair }(\%)=\frac{m_{b}-m_{k}}{m_{k}} 100 \%
$$

dengan $m_{b}$ adalah massa basah sampel setelah direndam $(\mathrm{g}), m_{k}$ adalah massa sampel kondisi kering oven $(\mathrm{g})$

\subsection{Pengujian Densitas}

Nilai densitas dilakukan dengan mengukur massa kering sampel dalam satuan gram dan mengukur panjang, lebar serta tebal sampel untuk mendapatkan volumenya dalam satuan $\mathrm{cm}^{3}$. Nilai densitas sampel uji dihitung menggunakan Persamaan 2.

$$
\rho=\frac{m}{v}
$$

dengan $\rho$ adalah densitas $\left(\mathrm{g} / \mathrm{cm}^{3}\right), m$ adalah massa $(\mathrm{g}), V$ adalah volume $\left(\mathrm{cm}^{3}\right)$.

\subsection{Pengujian Kuat Lentur}

Mula-mula sampel diukur lebar dan tebalnya dengan jangka sorong dan dicatat hasil pengukuran. Kemudian dilakukan pengujian kuat lentur menggunakan mesin UTM dengan meletakkan sampel secara mendatar pada tumpuan. Sampel diberikan beban pada bagian pusat dan dicatat perubahan sampel akibat diberi beban secara vertikal hingga sampel uji patah. Nilai kuat lentur dapat dihitung menggunakan Persamaan 3.

$$
f_{r}=\frac{3 m_{p} s}{2 L T^{2}}
$$

dengan $f_{r}$ adalah kuat lentur $\left(\mathrm{kg} / \mathrm{cm}^{3}\right), m_{p}$ adalah beban patah maksimum $(\mathrm{kg}), S$ adalah jarak tumpuan $(\mathrm{cm}), L$ adalah lebar sampel uji $(\mathrm{cm})$ dan $T$ adalah tinggi sampel $(\mathrm{cm})$.

\subsection{Pengujian Kuat Tekan}

Mula-mula sampel diukur panjang, lebar dan tebal dengan menggunakan jangka sorong dan hasil dicatat. Kemudian sampel uji diberi beban secara vertikal dan dicatat perubahan sampel akibat diberi beban maksimum secara vertikal hingga sampel uji retak. Nilai kuat tekan dapat dihitung menggunakan Persamaan 4.

$$
f_{c}=\frac{P}{A}
$$

dengan $f_{c}$ adalah kuat tekan $\left(\mathrm{kg} / \mathrm{cm}^{2}\right), P$ adalah beban retak maksimum sampel $(\mathrm{kg})$ dan $A$ adalah luas permukaan sampel $\left(\mathrm{cm}^{2}\right)$.

\subsection{Pengujian Porositas}

Pengujian porositas dilakukan pada sampel uji daya serap air. Perhitungan porositas dapat dilakukan denggan menggunakan Persamaan 5.

$$
\text { Porositas }(\%)=\frac{m_{b}-m}{V} \frac{1}{\rho}
$$


dengan $P$ adalah porositas $(\%), m_{b}$ adalah massa basah $(\mathrm{g}), \quad m$ adalah massa sampel kondisi kering $(\mathrm{g}), V$ adalah volume sampel $\left(\mathrm{cm}^{3}\right)$ dan $\rho$ adalah massa jenis air yaitu $1 \mathrm{~g} / \mathrm{cm}$.

\section{HASIL DAN DISKUSI}

\subsection{Densitas}

Gambar 1 menunjukan nilai densitas variasi persentase sekam padi pada papan beton ringan. Sampel dengan persentase sekam padi $0 \%$ memiliki densitas tertinggi yaitu $1,63 \mathrm{~g} / \mathrm{cm}^{3}$, jika dibandingkan dengan penambahan sekam pagi 10\%,20\%,30\% dan $40 \%$ yang menurun seiring pertambahan persentase sekam padi. Dengan nilai densitas terendah berada pada persentase $40 \%$ yatu $1,48 \mathrm{~g} / \mathrm{cm}^{3}$, hal ini dikarenakan penambahan sekam padi $40 \%$ menyebabkan persentase pasir dikurangkan sebanyak persentase sekam padi. Sehingga menghasilkan papan beton menjadi lebih ringan karena adanya tambahan agregat ringan berupa sekam padi. Papan beton ringan variasi sekam padi memenuhi standar mutu SNI 03-3449-2002 dengan nilai $<1,90 \mathrm{~g} / \mathrm{cm}^{3}$.

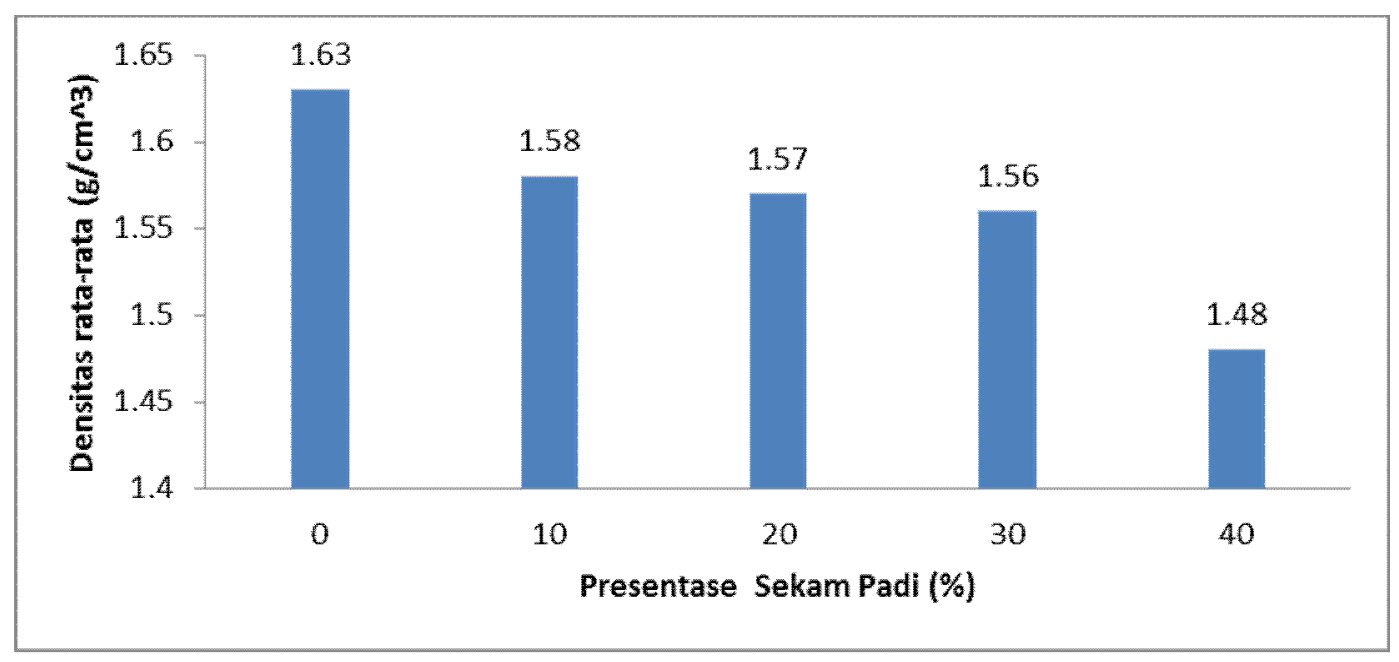

Gambar 1 Pengaruh persentase sekam padi terhadap densitas papan beton ringan

Hasil pengujian yang diperoleh dari papan beton ringan variasi sekam padi memenuhi SNI 03-3449-2002 dengan nilai densitas $<1,90 \mathrm{~g} / \mathrm{cm}^{3}$, dan nilai densitas papan beton ringan ini lebih kecil dibandingkan dengan papan GRC yang nilainya $1,77 \mathrm{~g} / \mathrm{cm}^{3}$.

\subsection{Daya Serap Air}

Gambar 2 menunjukan nilai daya serap air pada papan beton ringan variasi sekam padi.

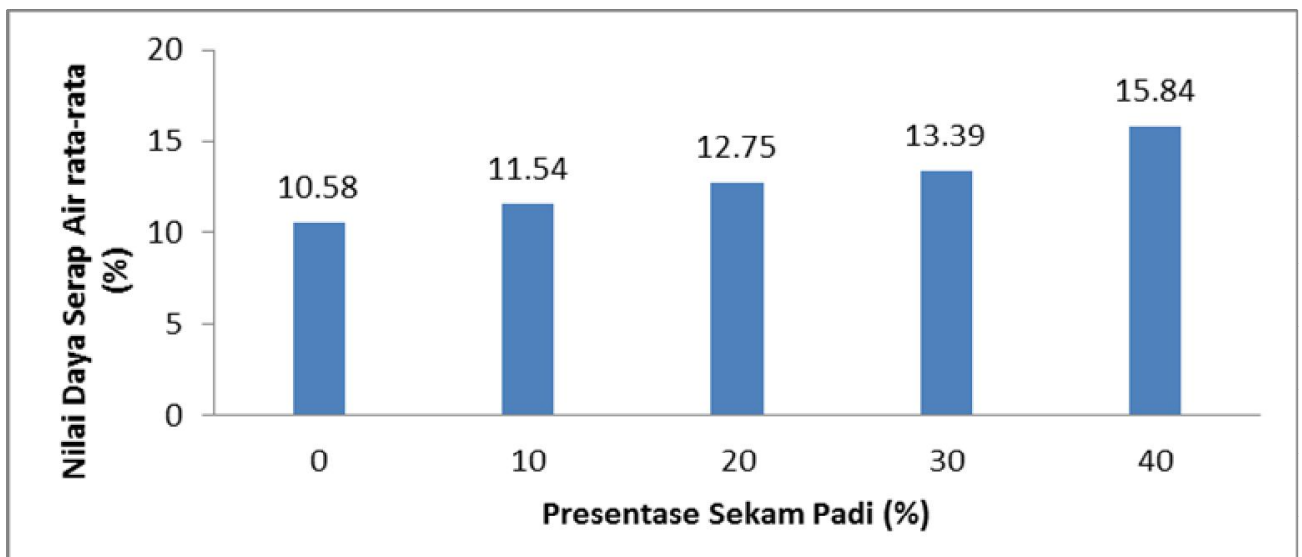

Gambar 2 Pengaruh persentase sekam padi terhadap nilai daya serap air papan beton ringan 
Nilai daya serap air terendah berada pada persentase $0 \%$ dan diikuti pada persentase $10 \%$ dengan nilai masing-masingnya $10,58 \%$ dan $11,54 \%$. Dengan nilai daya serap air tertinggi berada pada persentase $40 \%$ yaitu $15,84 \%$. Meningkatnya nilai daya serap air pada persentase 40\% dikarenakan penambahan sekam padi $40 \%$ mengakibatkan papan beton ringan menyerap banyak air pada saat perendaman dan sulit kering pada saat sampel dikeringkan. Hal ini dikarenakan sifat dari sekam padi sulit kering jika terkena air (Sisman dkk., 2011).

Jika dibandingkan dengan SNI 03-3449-2006 dengan nilai maks 14\%, maka papan GRC telah memenuhi standar. Berbeda dengan papan beton ringan variasi sekam padi, pada persentase $40 \%$ papan beton belum memenuhi standar yaitu $15,84 \%$. Perbedaan ini dikarenakan penambahan sekam padi sebesar $40 \%$.

\subsection{Porositas}

Gambar 3 menunjukan nilai porositas pada papan beton ringan variasi persentase sekam padi. Nilai terendah berada pada persentase $0 \%$ yaitu $17,26 \%$ dengan nilai tertinggi pada persentase $40 \%$ yaitu $23,78 \%$. Hal yang menyebabkan tingginya nilai porositas pada persentase $40 \%$ yaitu penambahan sekam padi yang terlalu banyak sehingga munculnya rongga-rongga pada papan beton ringan. Terdapatnya rongga-rongga udara menyebabkan papan memiliki densitas rendah dengan nilai daya serap air yang tinggi. Nilai porositas berbanding lurus dengan nilai daya serap air yang didapatkan.

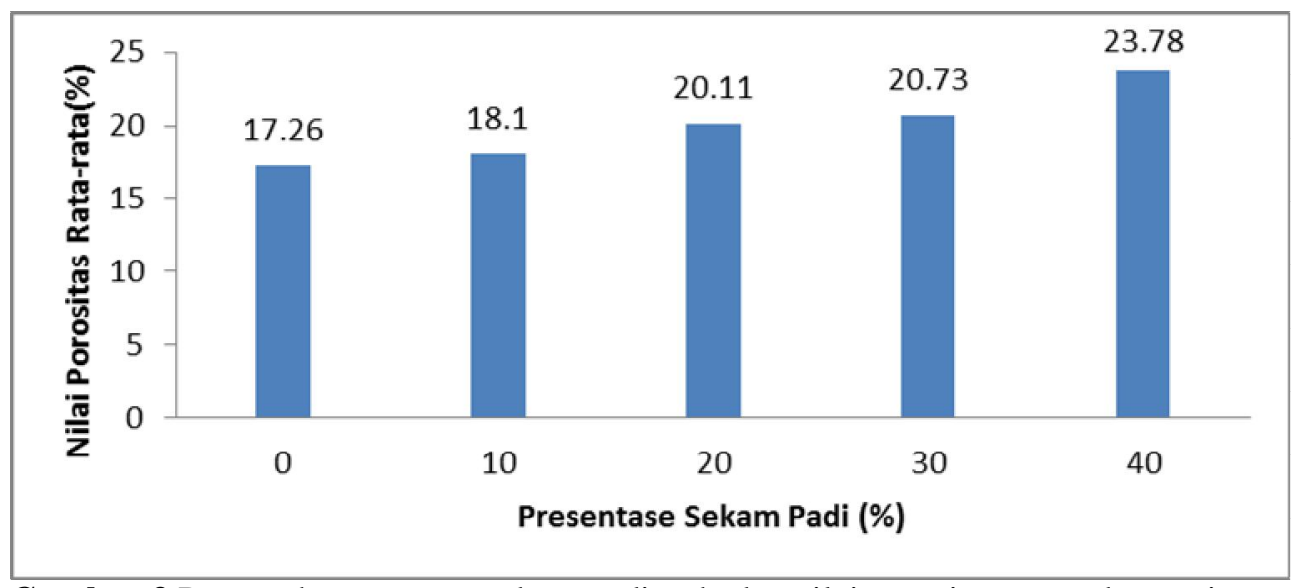

Gambar 3 Pengaruh persentase sekam padi terhadap nilai porositas papan beton ringan

\subsection{Kuat Tekan}

Gambar 4 menunjukan nilai kuat tekan yang didapatkan pada papan beton ringan variasi persentase sekam padi. Dapat dilihat nilai maksimum penambahan sekam padi pada papan beton ringan terdapat pada persentase $10 \%$ yaitu $56,33 \mathrm{~kg} / \mathrm{cm}^{2}$. Dengan nilai terendah pada persentase $40 \%$ yaitu $40,87 \mathrm{~kg} / \mathrm{cm}^{2}$. Perbedaan nilai kuat tekan pada tiap-tiap papan beton ringan membuktikan bahwa sekam padi berpengaruh pada kuat tekan papan. Nilai kuat tekan menurun karena ikatan antarmuka (interface) antara serat dan matriks menjadi lemah karena jumlahnya yang semakin banyak. Lemahnya ikatan antarmuka berdampak pada kekuatan papan beton ringan yaitu menjadikan papan tidak mampu menahan beban yang diberikan.

Penambahan sekam padi pada papan beton ringan dapat digunakan sebagai konduktivitas termal bagi papan struktural dan isolasi. Papan struktural dan isolasi sangat berguna sehingga bahan yang dihasilkan dapat digunakan terutama di bangunan budaya agri. Karena mereka membutuhkan bahan yang memiliki isolasi dan biaya yang rendah jika dibandingkan dengan sifat-sifat beton lainnya begitu juga untuk nilai kuat lenturnya. 


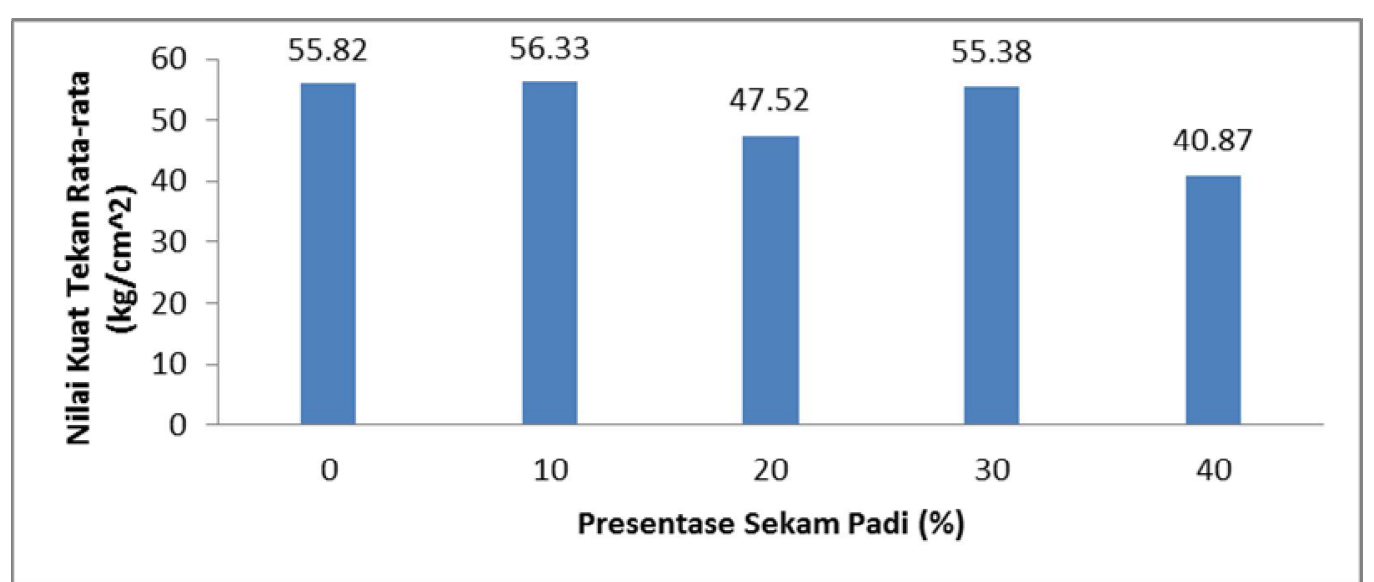

Gambar 4 Pengaruh persentase sekam padi terhadap nilai kuat tekan papan beton ringan

\subsection{Kuat Lentur}

Gambar 5 menunjukan nilai kuat lentur yang diperoleh pada papan beton ringan variasi persentase sekam padi. Nilai kuat lentur maksimal diperoleh pada persentase $10 \%$ yaitu 38,83 $\mathrm{kg} / \mathrm{cm}^{2}$ dengan nilai terendah berada pada persentase $40 \%$ yaitu $16,90 \mathrm{~kg} / \mathrm{cm}^{2}$. Dapat dilihat bahwa penurunan nilai kuat lentur seiring dengan penambahan sekam padi. Hal ini juga diperkuat dengan penelitian Tata dkk., (2016) menyatakan penambahan ASP antara 0\% hingga batas optimum akan menyebabkan peningkatan pada nilai kuat lentur. Hal ini dikarenakan penambahan ASP yang relatif sedikit dapat menutupi rongga udara dan menggurangi keretakan sehingga papan beton dapat menahan beban hingga batas optimum yang menyebabkan terjadinya lentur dan deformasi yang relatif sedikit.

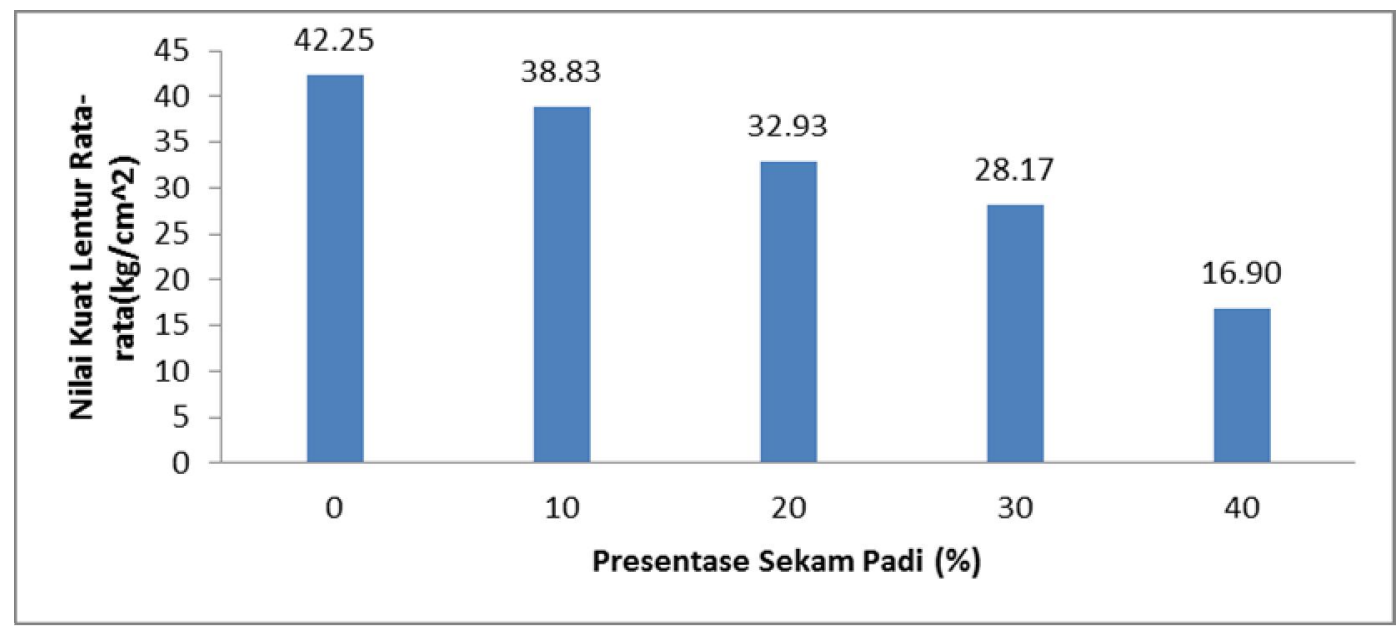

Gambar 5 Pengaruh persentase sekam padi terhadap nilai kuat tekan papan beton ringan

Kuat lentur menurun juga disebabkan karena ikatan antarmuka (interface) antara serat dan matrik menjadi lemah karena jumahnya yang semakin banyak. Lemahnya ikatan interface ini berdampak pada kekuatan sampel terhadap beban yang diberikan. Adapun dampaknya yaitu menjadi sampel tidak mampu menahan beban yang diberikan. Sehingga nilai kuat lentur yang dihasilkan akan menurun. Jika dibandingkan dengan standar mutu GRCA (Glassfibre Reinforceed Concrete Association) dengan nilai 203,947-305,915 kg/ $\mathrm{cm}^{2}$, papan beton ringan variasi sekam padi masih jauh dibawah GRCA.

\section{KESIMPULAN}

Sekam padi dapat digunakan sebagai pengurang agregat halus bagi papan beton ringan sehingga memiliki densitas yang rendah dibawah $1,90 \mathrm{~g} / \mathrm{cm}^{3}$. Papan beton variasi sekam padi yang dihasilkan pada persentase $40 \%$ untuk daya serap air belum memenuhi standar mutu SNI 
03-2105-2006 dengan nilai 15,84\%. Penambahan sekam padi berpengaruh terhadap sifat mekanik papan beton ringan. Penambahan maksimum sekam padi pada papan beton ringan untuk kuat tekan diperoleh pada persentase $10 \%$ yaitu $56,33 \mathrm{~kg} / \mathrm{cm}^{2}$, hampir mendekati nilai minimum standar mutu SNI 03-3449-2002 yaitu $68,9 \mathrm{~kg} / \mathrm{cm}^{2}$. Penambahan maksimum sekam padi untuk kuat lentur terdapat pada persentase $10 \%$ yaitu $38,83 \mathrm{~kg} / \mathrm{cm}^{2}$.

\section{DAFTAR PUSTAKA}

Badan Standardisasi Nasional (BSN), SN 03-3449-2002, Tata Cara Rencana Pembuatan Campuran Beton Ringan Dengan Agregat Ringan, Indonesia, 2002.

Badan Standarisasi Nasional (BSN), SNI 03-2105-2006, Papan Partikel, Indonesia,2006.

Renreng, I., Analisis Kekuatan Tarik Komposit Serat Kelapa (Cocos Nucifera) dengan Perlakuan Curcuma Domestica, Jurusan Mekanikal, Jurusan Teknik Mesin, Fakultas Mesin, Universitas Hasanuddin, 6,2015,

Sylvia, Y., Pengaruh Persentase Serat Sabut Pinang (Areca Catechu L. Fiber) Terhadap Sifat Mekanik dan Fisik Papan Gipsum-Beton, Jurusan Fisika, Universitas Andalas, JFU, Padang, 6, 188-193 (2017)

Sisman, C, Gezer,E dan Kocaman, I.," Effects Of Organic Waste (Rice Husk) On The Concrete Properties For Farm Buildings, Namik Kemal University”, Agricultural Faculty, Farm Constructions and Irrigation Department TR 59030, Tekirdag, Turkey, Bulgarian Journal of Agricultural Science, 1, 40-48 (2011)

Widiatmoko, S., Sukanto, H., Joko, P,W., "Pengaruh Penambahan Sekam Padi Terhadap Kuat Tekan Dan Penyerapan Air Bata Ringan Jenis Cellular Lightweight Concrete", Jurnal Teknik Mesin Indonesia, 11, 31-35 (2016) 